myśl, że żaden z Kościołów nie może stanowić wspólnoty (communio) sam dla siebie, a jedynie między sobą, tak jak nieugięcie zachowywali jedność wspólnot Apostołowie i ich następcy, i jak chciał tego nasz Pan. W świetle nieustannych wysiłków Ojca św. Jana Pawła II na rzecz takiej właśnie jedności, oraz Jego ostatnich podróży apostolskich do Egiptu, Grecji i Syrii, słowa tłumaczy i wydana przez nich praca nabierają dodatkowego znaczenia.

Ks. Arkadiusz Nocoń - Rzym

\title{
Ks. Jan BIAŁOBOK, Instytucja rodziców chrzestnych w ustawodawstwie Kościoła rzymsko-katolickiego (studium historyczno-prawne), Tarnów 2001, Biblos, ss. 299.
}

Współczesny prawodawca kościelny podkreśla, że „,sprawowanie chrztu powinno być odpowiednio przygotowane” (KPK kan. 851), co oznacza w przypadku rodziców i rodziców chrzestnych, obowiązek „należytego” pouczenia przez proboszcza lub innych prezbiterów „o znaczeniu tego sakramentu i o związanych z nim obowiązkach” (KPK kan. 851, $2^{\circ}$ ). Składać się na nie mają ,pasterskie pouczenie, a także wspólna modlitwa" (tamże). I chociaż w nowym obrzędzie chrztu zadania i czynności rodziców dziecka są o wiele bardziej wyeksponowane niż chrzestnych ${ }^{1}$, to jednak w księdze Kodeksu Prawa Kanonicznego poświęconej uświęcającemu zadaniu Kościoła, przeznaczono im specjalny rozdział (Chrzestni, KPK kan. 872-874). Obecność chrzestnych podczas celebracji tego sakramentu stanowi regułę, która dopuszcza wyjątki, a więc także brak ich obecności. Wówczas należy zatroszczyć się o to, „ażeby był przynajmniej jeden świadek, który by mógł stwierdzić udzielenie chrztu" (KPK kan. 875). Różnica zaś pomiędzy chrzestnym a świadkiem sprowadza się do tego, że „pierwszy wykonuje w obrzędzie chrztu przewidziane dla niego funkcje i podejmuje na przyszłość pewne zobowiązania, podczas gdy świadek jest w zasadzie tylko obecny i może zaświadczyć o udzieleniu chrztu"2. Prawodawca wskazał też warunki, jakim winien czynić zadość ten, który pełni funkcję chrzestnego (chrzestnych) ${ }^{3}$. Bardziej dokładne wskazania znajdujemy w księgach liturgicznych ${ }^{4}$.

${ }^{1}$ Por. E. Sztafrowski, Podręcznik prawa kanonicznego, III, Warszawa 1986, 144: „Jest charakterystyczne, że w nowym obrzędzie chrztu mocno zaakcentowano rolę nat u raln y ch rodziców i to w pewnym sensie «kosztem» chrzestnych". Skróty, oprócz zaznaczonych w tekście, podajemy za: Encyklopedia Katolicka. Wykaz skrótów, oprac. J. Warmiński - E. Gigilewicz R. Sawa, wyd. 2 popr. i rozszerzone. Lublin 1993.

2 Sztafrowski III 146.

${ }^{3}$ KPK w kan. 873 poucza: „Należy wybrać jednego tylko chrzestnego lub chrzestną, albo dwoje chrzestnych" (por. KPK kan. 872-874).

${ }^{4}$ Sztafrowski III 146. 
Jak każda sytuacja w Kościele, tak i ta posiada swą historię, a kościelna działalność ustawodawcza, dotycząca rodziców chrzestnych i kształtowana od początku chrześcijaństwa „okazała się niezbędną i wspomagającą przy udzielaniu chrztu nawet odnośnie - zdawać by się mogło - tak drugorzędnego działania, jak funkcja rodziców chrzestnych, której powstanie okazało się konieczne, celem zapewnienia bezpieczeństwa w okresie prześladowań przez 2000 lat utrzymywała swą aktualność w wielorakich aspektach, szczególnie pedagogicznym i opiekuńczym, kształtowana postanowieniami kompetentnej władzy, zawartymi w Corpus Iuris Canonici z 1917 i 1983 roku, jak również w statutach synodalnych i rubrykach rytuałów oraz agend liturgicznych" (Stowo wstępne s. 27).

Praca, którą pragniemy tu omówić, składa się z trzech części i aneksu'. Do tego dochodzi jeszcze bogata bibliografia źródeł i przedmiotu (s. 9-24). Podział treści jest logiczny. Autor studium zawarł dostępny mu materiał w trzech częściach, które wiążą się z ważnymi wydarzeniami życia Kościoła, a mianowicie: (1) Soborem Trydenckim, (2) reformą potrydencką oraz (3) kodyfikacją prawa kościelnego w 1917 i 1983 roku.

Już przeczytanie Spisu treści pozwala na domniemanie, iż część trzecia książki i Aneks nie przynależały do jej pierwotnego zasobu, a zostały dopisane na wyraźne życzenie Wydawnictwa, ze szkodą dla jej Autora i tematu. Przekonanie to wzmacnia uwaga Autora w Słowie wstepnym ${ }^{6}$ oraz nota bibliograficzna w haśle Chrzestni rodzice ${ }^{7}$, w której znajdujemy pierwotny tytuł pracy (Instytucja rodziców chrzestnych w ustawodawstwie Kościoła zachodniego. Studium historyczno-prawne, Lublin 1960, mps BKUL) oraz nie podany w Bibliografii artykuł Autora dotyczący tematu publikacji ${ }^{8}$. Tak więc wydawca popełnił podstawowy błąd metodologiczny, a mianowicie nie podał informacji o czasie powstania rozprawy, co pozwoliłoby Czytelnikowi na pominięcie - już w trakcie czytania - uwag na temat datowania poszczególnych dokumentów,

${ }^{5}$ Cz. I: Instytucja rodziców chrzestnych przed Soborem Trydenckim s. 31-117 (1. Geneza i rozwój instytucji rodziców chrzestnych w świetle najstarszych źródet; 2. Podmiot urzędu rodziców chrzestnych; 3. Skutki prawne spetniania urzędu rodziców chrzestnych); Cz. II: Instytucja rodziców chrzestnych od Soboru Trydenckiego do Kodeksu Prawa Kanonicznego s. 118-258 (1. Instytucja rodziców chrzestnych w ustawodawstwie powszechnym i jego autentycznej interpretacji; 2 . Instytucja rodziców chrzestnych $w$ ustawodawstwie partykularnym; 3. Instytucja rodziców chrzestnych w zwyczajach polskich XVIII $i$ XIX $w$.); Cz. III: Instytucja rodziców chrzestnych $w$ Kodeksie Prawa Kanonicznego z 1917 r. s. 258-294 (1. Pojęcie instytucji rodziców chrzestnych;2. O konieczności powołania rodziców chrzestnych; 3. Liczba oraz kwalifikacje rodziców chrzestnych wymagane do ważnego i godziwego spelniania urzędu; 4. Skutki prawne instytucji rodziców chrzestnych); Aneks: Instytucja rodziców chrzestnych w Kodeksie Prawa Kanonicznego z 1983 r. s. 295-299).

6 „Wydanie tejże pracy napisanej na Wydziale Prawa Kanonicznego Katolickiego Uniwersytetu Lubelskiego pod kierunkiem Prof. Dr hab. Ks. Jana Nowickiego może być małym przyczynkiem do polskiej literatury historyczno-prawnej" (s. 28).

${ }^{7}$ Por. P. Hemperek, Chrzestni rodzice, EK III 378.

${ }^{8}$ Por. J. Białobok, Instytucja rodziców chrzestnych w kodeksie prawa kanonicznego, „Currenda" 112 (1962) 253-270. 
braku współczesnej literatury odnośnie tego zagadnienia (w tym francuskiej) lub okołoproblemowej, by wspomnieć tylko o opracowaniu Romana Murawskiego SDB, profesora UKSW w Warszawie (Wczesnochrześcijańska katecheza. Do Edyktu Mediolańskiego - 313 roku, Płock 1999).

Należy podkreślić, że mimo wskazanych obiekcji prezentowane studium jest bardzo ważną publikacją, która winna zainteresować nie tylko historyków prawa kościelnego, w tym prawa partykularnego, ale także patrologów, bo zakres przedstawionego materiału dotyka tradycji Kościoła oraz teologów pastoralistów, a konkretnie historyków liturgii.

1. W części pierwszej książki Autor podjął zadanie określenia genezy i rozwoju instytucji rodziców chrzestnych, ich liczby i płci oraz obowiązków i skutków prawnych wynikających ze spełniania tego urzędu. Swymi badaniami objął okres historii Kościoła od III wieku do Soboru Trydenckiego. Na temat przyczyn powstania tej instytucji wymienia się cztery opinie ${ }^{9}, \mathrm{z}$ których słuszną okazuje się przekonanie, że jej zaistnienie wiąże się z powstaniem i rozwojem katechumenatu i chrztem dzieci. Dorośli spełniali wówczas wobec nawracających się pogan rolę lub funkcję świadka - poręczyciela (fideiussor), pomocnika (susceptor) przy samym obrzędzie udzielania sakramentu i poręczyciela składającego przyrzeczenia i wyznanie wiary w imieniu ochrzczonych dzieci (sponsores infantium). Z upływem czasu $\mathrm{z}$ tych trzech form wykształciła się jedna instytucja chrzestnych (patrini), a sama nazwa pojawiła się w VIII wieku (s. 70) ${ }^{10}$.

Jeśli chodzi o przepisy, dotyczące liczby i płci rodziców chrzestnych, to ze świadectw starożytnych wynika, że w pierwszych wiekach „nie znano później powstałego zwyczaju powoływania do chrztu większej liczby rodziców chrzestnych (...). Ciekawym i jedynym wyjątkiem są tutaj Canones Hipolyti, w których czytamy, że warunkiem przyjęcia katechumenatu, a później warunkiem otrzymania chrztu, były pozytywne świadectwa trzech świadków (...). Początkowo nie było również przepisu nakazującego, aby każdy miał własnego ojca chrzestnego, względnie własną chrzestną matkę" (s. 71). Liczba rodziców chrzestnych w dziejach Kościoła podlegała zmianom: od jednego lub jednej po dwadzieścia osób, przy chrzcie potomków szlacheckich rodów Wenecji. W Kościele stale jednak istniała tendencja do wyraźnego ograniczania liczby rodziców chrzestnych do dwojga (mężczyzny i kobiety) ${ }^{11}$.

${ }^{9}$ 1. L. Saksoński († 1377) na podstawie J 1, 42 twierdził, że rola św. Andrzeja Apostoła, brata Szymona-Piotra, miała taki charakter; 2 . Zapożyczenia ze starotestamentalnego ceremoniału przyjęcia poganina; 3 . Wpływ urzędu mystagoga, który wprowadzał nowicjuszy w misteria eleuzyjskie; 4. Instytucja katechumenatu.

${ }^{10} \mathrm{~W}$ nawiasach zamieszczamy strony z książki ks. Białoboka, na które się powołujemy.

11 Por. tamże, s. 87-88: „Od początku chrześcijaństwa do pierwszej połowy IX w. znany był i tolerowany w Kościele zwyczaj, że w wielu wypadkach funkcję rodziców chrzestnych spełniali rodzice naturalni przy chrzcie własnych dzieci (...). Zwyczaj ten zaczyna powoli wychodzić z praktyki dopiero na skutek przepisu wydanego na synodzie odbytym w Metz (813 r.) (...) nie 
Od początku w chrześcijaństwie zdawano sobie sprawę ze znaczenia instytucji rodziców chrzestnych. Oznaczało to, że wymagania dotyczyły nie tylko ich przynależności do Kościoła przez chrzest i prawowierności w wierze, ale też „Znajomości podstaw nauki katolickiej w tym celu, aby mogli wobec swoich chrześniaków skutecznie spełniać obowiązek nauczania. (s. 94). Święty Hieronim obowiązek ten określa terminem ministerium verbi (tamże).

2. „Sobór Trydencki (...) wśród zagadnień dyscyplinarnych nie pominął również problemu instytucji rodziców chrzestnych. W rozdziale zatytułowanym Inter quos cognatio spiritualis contrahaur zamieścił ustawodawca, wprawdzie nieliczne, ale ważne postanowienia odnoszące się do urzędu rodziców chrzestnych. Niektóre z nich mają charakter ustaw, inne zaś rozporządzeń wykonawczych" (s. 117). Sprawy te zostały przez naszego Autora omówione w części drugiej przedstawionej pracy i dotyczą liczby rodziców chrzestnych: „(...) urząd rodziców chrzestnych przy chrzcie mogą spełniać: tylko jeden mężczyzna albo jedna kobieta, względnie co najwyżej jeden mężczyzna z jedna kobietą" (s. 118), zasięgu pokrewieństwa duchowego, zgodności ustaw partykularnych z ustawodawstwem trydenckim, nakazu prowadzenia ksiąg ochrzczonych i zapisywania w nich także imion rodziców chrzestnych.

Formalny wykład instytucji rodziców chrzestnych, zgodny z rozporządzeniami i duchem Soboru Trydenckiego, znajdujemy w wydanym przez papieża Piusa V Katechizmie Rzymskim. Zawarta w nim nauka „składa się z pięciu kwestii (XXV-XXIX). Autor nasz poucza o istocie urzędu, obowiązkach i kwalifikacjach rodziców chrzestnych oraz przytacza z krótkimi komentarzami ustawy Soboru dotyczące tej instytucji” (s. 127). W ten sposób chciano zaradzić niedbale spełnianej i lekceważonej w tym czasie ważnej instytucji: „Rodzice chrzestni mają obowiązek (...) wyręczać kapłanów w nauczaniu zasad wiary, pomagając im w ten sposób w akcji duszpasterskiej. Proboszczowie bowiem postawieni nad całą parafią i obciązeni obowiązkiem duszpasterstwa powszechnego, nie mają tyle czasu, aby prywatnie zajmować się wychowaniem i nauczaniem każdego z osobna (...). [Rodzice chrzestni na mocy chrztu] stali się poręczycielami wobec Boga za cnotliwe i chrześcijańskie życie swoich duchowych dzieci i przed Bogiem będą odpowiadali za ich postępowanie" (s. 129131). Potrydencka reforma instytucji rodziców chrzestnych poświęciła także uwagę w wydanym Rytuale rzymskim, wskazując na odpowiednie ich kwalifikacje. Zagadnienie to zresztą zostało podjęte przez Stolice Apostolską później, w specjalnej instrukcji papieża Benedykta XIV (1740-1758), co świadczy o szczególnej uwadze Kościoła odnośnie tej sprawy.

Interesujące w tej części pracy są te partie materiału, które nasz Autor poświęcił polskiemu partykularnemu prawodawstwu synodalnemu (s. 217-

znajdujemy natomiast przepisu, który by zabranial dzieciom spełniać urząd rodziców chrzestnych wobec własnych rodziców naturalnych" 
242) oraz zwyczajom polskim XVIII i XIX wieku (s. 243-258). Ze zrozumiałych względów nie zajmiemy się nimi szczegółowo. Anonsujemy je tylko, by zorientować Czytelnika w treści książki.

3. Część trzecia przedstawionej tu pracy jest najkrótsza, bo zawiera prawie czterdzieści stron (s. 258-294). Wraz z kilkustronicowym Aneksem (s. 295-299), w którym Autor poświęcił uwagę instytucji rodziców chrzestnych w nowym prawodawstwie kościelnym z 1983 roku, należy te partie książki rozumieć jako konieczne, aczkolwiek pobieżne dopełnienie problematyki szczegółowo podjętej w pierwszych dwóch częściach publikacji. Istnieje zatem potrzeba wnikliwego opracowania tego zagadnienia. Księdzu Janowi Białobokowi należą się gratulacje za słuszną decyzję opublikowania swojej pracy, która znajdzie swe należne miejsce wśród prac o historii instytucji, która obecnie domaga się nowego pastoralnego ujęcia.

Marek Marczewski - Lublin

\section{Dokumenty prvých dvoch Ekumenických snemov. $\mathrm{Z}$ gréčtiny přeložil, úvody

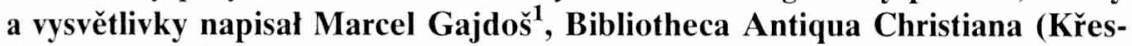 tanská antická bibliotéka). Edičný rad Fontes zv[äzok] Prešov 1999, Nábožen- ské vydavatel'stvo PETRA, ss. 46.}

W roku 1999 ukazał się pierwszy tom Listów św. Bazylego Wielkiego. Ich wydanie na zawsze pozostanie związane $\mathrm{z}$ otwarciem potrzebnego w Słowacji i długo tam oczekiwanego patrystycznego wydawnictwa ciągłego: Křestanská antická bibliotéka, o czym polski czytelnik dostał już należną informację². Jak tom Listów św. Bazylego Wielkiego z lat 357-374 należy do podserii Patrimonium, tak inną podserię Fontes otworzyły wyżej bibliograficznie opisane dokumenty dwóch pierwszych Soborów powszechnych: Nicejskiego (325) i I Konstantynopolitańskiego (381). Autor słowackiego przekładu przyjął za jego podstawę krytyczne wydanie ich greckiego tekstu przygotowanego przez N.P. Tannera ${ }^{3}$.

Zanim Autor zaprezentował sam słowacki przekład dokumentów soborowych poprzedził je krótkimi historycznymi wstępami (s. 3-6 i 27-30). Szczegółowe objaśnienia filologiczne i rzeczowe zostały umieszczone na końcu prze-

${ }^{1}$ Marek Gajdoš ur. 9. 1. 1974 Bratysława. Po ukończeniu gimnazjum Ivana Horvatha w Bratysławie (1992) zaczął studia na Wydziale Teologicznym Uniwersytetu J. Kmenskiego w Bratysławie. Od roku 1995 studia kontynuował na Greckokatolickim Wydziale Teologicznym z siedzibą w Preszowie należącym wtedy do Uniwersytetu J.P. Šafarika. Studia ukończył w roku 1997 nadaniem mu stopnia magisterskiego z teologii ogólnej.

2 Por. Recenzja w VoxP 19 (1999) t. 36-37, 525-529.

${ }^{3}$ Por. Decrees of the Ecumenical Councils, Vol. 1, Georgetowne 1990. 